European Journal of Business and Innovation Research

Vol.9, No.2, pp. 27-38, 2021

Print ISSN: 2053-4019(Print),

Online ISSN: 2053-4027(Online)

\title{
MULTIVARIATE ANALYSIS OF THE FACTORS THAT INFLUENCE STRATEGIC MANAGEMENT PRACTICES AMONG COMMERCIAL BANKS IN NIGERIA
}

\author{
Kingsley Lazaru Uwa (PhD) \\ Department of Business Administration, Faculty of Management Sciences \\ Akwa Ibom State University, Obio Akpa Campus, Nigeria
}

\begin{abstract}
Strategic management has been widely recognised as very potent tools for enhancing organisational performance, productivity and competitive advantage of organisations. Therefore, this study explores the use of one of the multivariate analysis (Principal Component Analysis) to determine factors that influence the strategic management practices of commercial banks in Nigeria. The study was guided by one objective and one research question. The descriptive survey research design was adopted and the population of the study comprised 1164 employees in the seventeen (17) commercial banks in Nigeria and a sample size of 298 employees of commercial banks was estimated using Taro Yamane Formula. The instrument used in data collection was Factors Affecting Strategic Management Practices Questionnaire (FASMPQ). The instrument was validated by experts and reliability of the instruments was established using Cronbach Alpha and result yielded reliability coefficient of 0.84. Data obtained were analyzed using Principal Component Analysis (PCA) and the result revealed that political and legal environment, demography, socio-cultural environment, economic environment and technological environment were the five major factors that influence strategic management practices. The findings also showed that environmental factors have major influence on strategic management practices among commercial banks in Nigeria. Therefore, it is recommended among other things that commercial banks in the study area should focus on the environmental factor such as political and legal environment, technological environment, economic environment, global and socio-cultural environment as these influence strategic management practices in commercial banks in Nigeria.
\end{abstract}

KEYWORDS: multivariate analysis, principal component analysis, strategic management practices.

\section{INTRODUCTION}

One of the sectors of the economy that has faced serious competition is the banking sector of which commercial banks is an integral part. The reason for this could be as a result of the fact that they offer similar services and they must do everything possible to remain in business. Also, due to market competition and other external challenges, firms make efforts to carry out systematic planning and decision making and this is where strategic management plays a critical role. Strategic management has been described by David (2005) as the "process and approach of specifying an organization's objectives, developing policies and plans to achieve and attain these objectives, and allocating resources so as to implement the policies and plans". Strategic 
European Journal of Business and Innovation Research

Vol.9, No.2, pp. 27-38, 2021

Print ISSN: 2053-4019(Print), Online ISSN: 2053-4027(Online)

management involves all set of actions that is needed for an organization to have a full understanding of both its external and internal environments; formulate its corporate, competitive and functional strategies.

Similarly, Strategic management in the word of Veskaisri, Chan and Pollard (2007) is the process of specifying the organization's mission, vision and objectives, developing policies and plans, often in terms of projects and programmes, which are designed to achieve these objectives and then allocating resources to implement the policies and plans, projects and programmes.

According to mintzberg 1998; Puck 1999; Richardson 1995, the benefits a company that applies strategic management includes-focus in setting directions, the company is distinguish among its competitors, stability in decision making process, mutual understanding and communication between the top and lower level managers and the employees. It also ensures an establishment of a systematic and logical problem solving system, rational distribution of resource among different units and then control to ensure orderliness. Although strategic management enables mastery of the dynamics of business environment, there has been criticism on strategic management especially where there is lack of strategic thinking. Strategic management put more efforts on analyzing the past hence cannot be relied on to generate solutions to present condition in the business environment (Hammonds, 2001 and Strebel, 2001).

Rechardson (1995) argues that one cannot challenge the application of strategic management although it application in some cases can be questionable. Strategic management critics categorize three problem areas that can reduce the expected result of strategic management practices, and they are; unsuitable philosophy for strategy formulation, use of incompetent procedure when analyzing data etc. Strategic management practices on the other hand is the process whereby managers establish an organisation's long-term direction, set specific performance objectives, develop strategies to achieve these objectives in the light of all the relevant internal and external circumstances, and undertake to execute the chosen action plans(Thompson and Strickland, 2003). Veskaisri, Chan and Pollard (2007) added that without a clearly defined strategy, a business will have no sustainable basis for creating and maintaining a competitive advantage in the industry where it operates and this could spell doom for any organization. This therefore means that effective strategic management could help enhance the competitive advantage of a firm and hence help in enhancing organizational performance. The role of strategic management practices on organizations has been widely acknowledged. It has been observed to have a positive relationship with organizational performance (Askarany and Yazdifar, 2012; Mohamud, Mohamud and Mohammed, 2015; Monday, Akinola, Ologbenla and Aladeraji, 2015). It also enhances organizational growth and competitive advantage (Olanipekun, Abioro, Akanni, Arulogun and Rabiu, 2015). 
European Journal of Business and Innovation Research

Vol.9, No.2, pp. 27-38, 2021

Print ISSN: 2053-4019(Print), Online ISSN: 2053-4027(Online)

Despite the significant role strategic management plays in organization, there is few studies on factors that influence strategic management practices in the banking sector using any multivariate analysis, the few available studies make use of models like correlation, means with standard deviation, regression or any other technique other than multivariate analysis precisely, factor analysis. Therefore, this study intends to bridge this research gap by examining the factors that influence strategic management practices in commercial banks using confirmatory factor analysis. The specific objective of this study is to determine the factors that influencing strategic management practices in commercial banks. This study is guided by the research question which is: what are the factors that influencing strategic management in commercial banks in Nigeria.

\section{REVIEW OF RELATED LITERATURES}

\section{Strategic management and strategic management practices}

The concept of strategic management has been defined by many scholars. Wheelen and Hunger (2007) noted that strategic management involves managerial decisions and actions that help in the formulation and implementation of strategy designed to achieve a company's goals. In the same vein, Thompson and Strickland (2007) views strategic management as the "process whereby managers establish an organisation's long-term direction, set specific performance objectives, development strategies to achieve these objectives in the light of all the relevant internal and external circumstances, and undertake to execute the chosen action plans". In the word of Muogbo (2013) strategic management is an on-going process that evaluates and controls the business and the industries in which the firm is involved, assesses its competitors, set goal and strategies to meet all existing and potential competitors and then reassesses each strategy to meet charged circumstances, new technology, new competitors, new economic environment or new social financial or political environment.

Strategic management practices in the word of Thompson and Strickland (2003) is the whereby managers set specific performance objectives, establish an organization's long-term direction, develop strategies to achieve these objectives in the light of all the relevant internal and external circumstances, and undertake to execute the chosen action plans. Adeleke, Ogundele and Oyenuga (2008), defines strategic management practice as the process of examining both present and future environments, formulating the organizations objectives, implementing and controlling decisions focused on achieving these objectives in the present and future environments.

Many factors have been identified to influence strategic management practices. Thompson (1998) classified these factors into three namely environmental factors (national economic conditions, national culture, and industry conditions), organizational factors (organizational structure, organisational culture, decision of board of directors, impact of upward influence, and employee involvement) and decision- specific factors (time, risk, complexity, and politics). 
European Journal of Business and Innovation Research

Vol.9, No.2, pp. 27-38, 2021

Print ISSN: 2053-4019(Print),

Online ISSN: 2053-4027(Online)

Kiptoo and Mwirigi (2014) also observed that organisational structure, organisational culture, leadership and human resources also influence strategic management practices while Sassi, Pihlak and Hadma (2017) classified factors that influence strategic management practices into external and internal factors. Similarly, Dominic and Theuvsen (2015) classified these factors into three which are firm characteristics (age, size, formulization status), firm resources (level of investment, information access, firm's expertise and pressure) and pressure from external environment ( extent of input availability, access to public infrastructure and access to external fund). It was concluded that strategic management performance tend to decline as a firm ages since younger organizations tend to easily pick up new practices unlike older firms which may find it difficult to drop old strategies and work procedure. Thompson and Strickland (2014) argues that older firms comfortably adjust to practices that emerge due to staff exceptional experience. Theresia and Ludwig (2015) argue that an organization potential to attain its objectives is influence by the resources it has and management of the resources. Their position is that, a well utilized resources enables better strategic practices.

This study is anchored on two theories, The Resource-Based Theory developed by Wernarfelt(1984) and formalized by Barnly(1991). The theory asserts that availability of resources to an organization can help such organization to have an edge over its competitors in the same industry. The theory is of the view that organizations' resources and bargaining power capabilities form the basis on which organizations compete. Wernerfelt (1984) proclaimed that a firm is deemed to achieve competitive edge over its rivals through the execution of strategies which exploit the internal strengths in response to environmental opportunities. Concomitantly, inner weaknesses can be avoided and outside threat neutralized.

The second theory is the Poter's five forces. According to Potter (1979), there are forces in the industry that determine the magnitude of competition and appeal of the market. Appeal of the market in this case stands for the likelihood to make profit. The five industry forces are; threat of entry of new competitors, intensity of competition from rivals, suppliers bargaining power, negation capacity of customers and threats from substitute products or services. The forces framework was to give answer to SWOT analysis of firms' competitiveness. Nevertheless, porter's five force model faced some criticism due to porter's inability to justify how he came by the five forces. Secondly, the model is considered by scholars to be too rigid because it is not easy to tell the market with the great competition intensity since market keeps changing.

\section{Empirical Review}

Kakunu (2012) determined factors that influence the banks strategic management practices in Kenya. The study adopted the descriptive design and the population of the study comprised 43 banks. Questionnaire was used in data collection and data was analysed using descriptive 
European Journal of Business and Innovation Research

Vol.9, No.2, pp. 27-38, 2021

Print ISSN: 2053-4019(Print), Online ISSN: 2053-4027(Online)

analysis. Finding showed that the most significant factors that influence strategic management practices were technological environment, economic environment, global environment, political and legal environment, bank structure, bank resources, and socio-cultural environment. The finding also revealed that strategic management in commercial banks was highly influenced by both internal factors and external factors.

Zhiping (2016) determined factors affecting effectiveness of strategic management between Kenyan owned ceramic firms and Chinese owned ceramic enterprises in Kenya. This research was a descriptive study in nature. The population for the study was 170 Kenyan and Chinese managers and entrepreneurs who have engaged in ceramic business in Kenya. The sample size for this study was 33 Kenyan and Chinese managers in total 11 from Housemart and 22 from Tile \& Carpet and SAJ. The study was carried out within Nairobi CBD especially along Mombasa Road where ceramic business is a thriving business. The data collected was analyzed by the use of inferential and descriptive statistics. The finding showed that strategic approaches, organizational cultures and core competences do have strong influences on the effectiveness of strategic management of ceramic firms in Kenya. Each factor can either work independently or together to determine the success of strategic management of ceramic business among carried out. None of these studies adopt the multivariate method but rather draw inference on factors that influence strategic management practices based on descriptive statistics

\section{METHODOLOGY}

The study adopted the survey research design. The choice of this design was informed by the nature of the research problem and the objectives of the study. The population for this study comprises 1164 employees in the seventeen (17) deposit money banks in Nigeria and a sample size of 298 employees of commercial banks was estimated using Taro Yamane Questionnaire. The instrument used in data collection is an adapted questionnaire from The instrument tagged Factors Affecting Strategic Management Practices Questionnaire (FASMPQ) was adapted from Kakunu (2012) and comprised 19 items rated on five points rating scale of very large extent ( 5 points), large extent( 4 points), average extent ( 3 points), low extent( 2 points) and very low extent(1 point). The Factors Affecting Strategic Management Practices Questionnaire (FASMPQ) was validated by experts and reliability of the instruments was established using Cronbach Alpha and result yielded reliability coefficient of 0.84 . Data obtained was analyze using factor analysis. To enhance data analysis and computation of results, the Statistical Package for Social Sciences (SPSS version 22.0) was used. 
European Journal of Business and Innovation Research

Vol.9, No.2, pp. 27-38, 2021

Print ISSN: 2053-4019(Print), Online ISSN: 2053-4027(Online)

Table 1: Summary of the Eigenvalues for the factors affecting strategic management practices in commercial banks.

\begin{tabular}{|c|c|c|c|c|c|c|c|c|c|}
\hline \multirow[t]{2}{*}{ Component } & \multicolumn{3}{|c|}{ Initial Eigenvalues } & \multicolumn{3}{|c|}{ Extraction Sums of Squared Loadings } & \multirow{2}{*}{$\begin{array}{l}\text { Rotation } \\
\text { Loadings } \\
\text { Total }\end{array}$} & \multirow{2}{*}{$\begin{array}{l}\text { Sums of } \\
\% \text { of } \\
\text { Variance }\end{array}$} & \multirow{2}{*}{$\begin{array}{l}\text { Squared } \\
\text { Cumul } \\
\text { ative } \\
\%\end{array}$} \\
\hline & Total & $\begin{array}{l}\% \text { of } \\
\text { Variance }\end{array}$ & $\begin{array}{l}\text { Cumulative } \\
\%\end{array}$ & Total & $\begin{array}{l}\% \text { of } \\
\text { Variance }\end{array}$ & $\begin{array}{l}\text { Cumulative } \\
\%\end{array}$ & & & \\
\hline 1 & 5.740 & 30.212 & 30.212 & 5.740 & 30.212 & 30.212 & 4.129 & 21.732 & 21.732 \\
\hline 2 & 2.569 & 13.523 & 43.735 & 2.569 & 13.523 & 43.735 & 2.433 & 12.805 & 34.537 \\
\hline 3 & 2.294 & 12.076 & 55.811 & 2.294 & 12.076 & 55.811 & 2.392 & 12.587 & 47.124 \\
\hline 4 & 1.864 & 9.810 & 65.621 & 1.864 & 9.810 & 65.621 & 2.262 & 11.906 & 59.031 \\
\hline 5 & 1.226 & 6.454 & 72.075 & 1.226 & 6.454 & 72.075 & 2.229 & 11.733 & 70.764 \\
\hline 6 & 1.182 & 6.221 & 78.296 & 1.182 & 6.221 & 78.296 & 1.431 & 7.532 & 78.296 \\
\hline 7 & .976 & 5.138 & 83.434 & & & & & & \\
\hline 8 & .679 & 3.575 & 87.009 & & & & & & \\
\hline 9 & .568 & 2.989 & 89.998 & & & & & & \\
\hline 10 & .438 & 2.306 & 92.305 & & & & & & \\
\hline 11 & .425 & 2.239 & 94.544 & & & & & & \\
\hline 12 & .329 & 1.734 & 96.278 & & & & & & \\
\hline 13 & .204 & 1.075 & 97.353 & & & & & & \\
\hline 14 & .171 & .903 & 98.256 & & & & & & \\
\hline 15 & .104 & .549 & 98.804 & & & & & & \\
\hline 16 & .088 & .464 & 99.268 & & & & & & \\
\hline 17 & .073 & .384 & 99.652 & & & & & & \\
\hline 18 & .036 & .191 & 99.843 & & & & & & \\
\hline 19 & .030 & .157 & 100.000 & & & & & & \\
\hline
\end{tabular}


European Journal of Business and Innovation Research

Vol.9, No.2, pp. 27-38, 2021

Print ISSN: 2053-4019(Print),

Online ISSN: 2053-4027(Online)

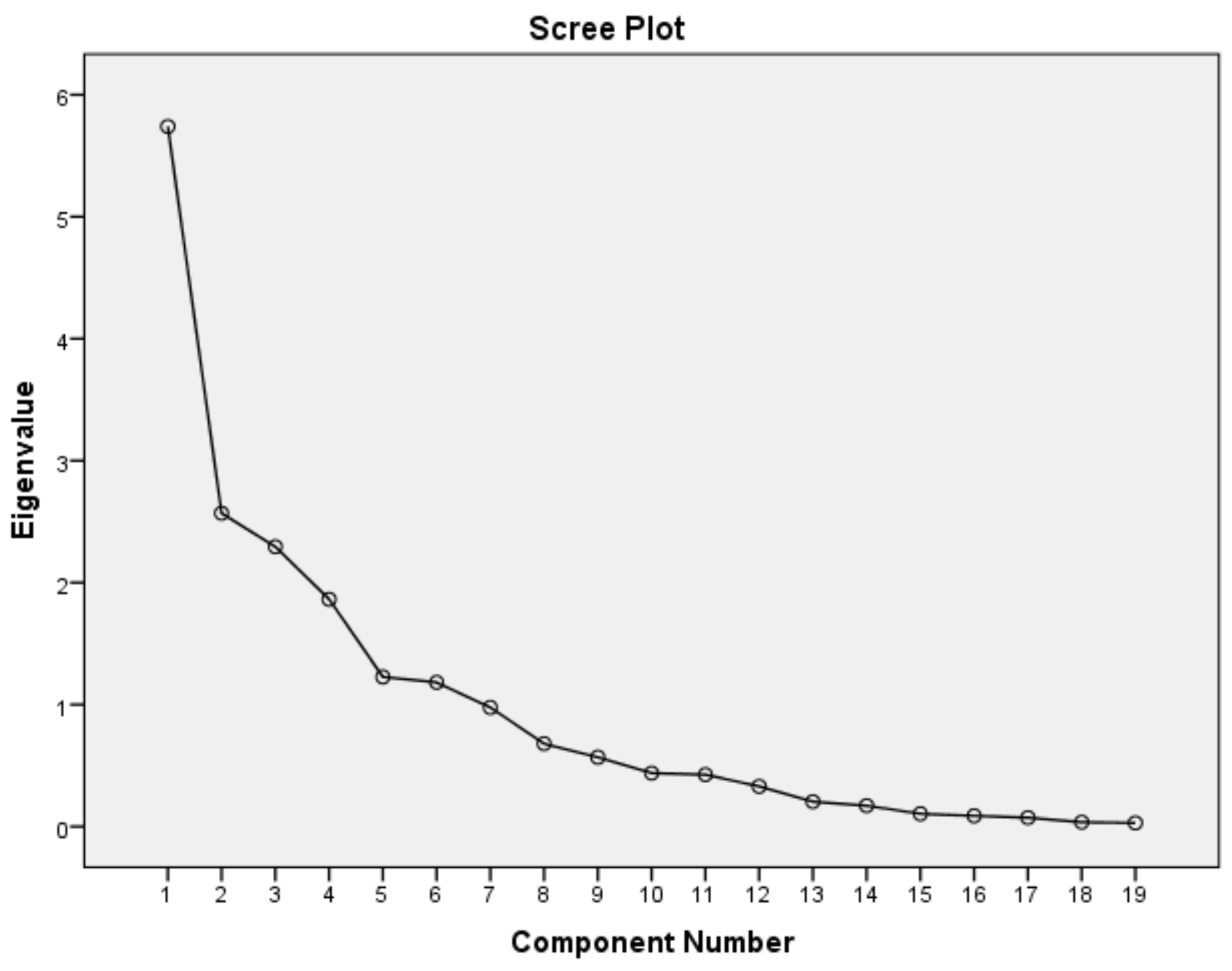

Fig 1 : Screen plot showing eigenvalues greater than 1 . 
European Journal of Business and Innovation Research

Vol.9, No.2, pp. 27-38, 2021

Print ISSN: 2053-4019(Print), Online ISSN: 2053-4027(Online)

Table 2: Rotated Factor loadings between each of the factors and the extracted six components

\begin{tabular}{|c|c|c|c|c|c|c|}
\hline & \multicolumn{6}{|c|}{ Components } \\
\hline & 1 & 2 & 3 & 4 & 5 & 6 \\
\hline $\begin{array}{l}\text { Political and legal } \\
\text { environment } \\
\text { Economic environment } \\
\text { Technological } \\
\text { environment } \\
\text { Global environment } \\
\text { Entry new banks in the } \\
\text { market substitute } \\
\text { Threat of sut } \\
\text { products in the market } \\
\text { Bargaining power of } \\
\text { suppliers power of } \\
\text { Bargaining purs } \\
\text { customers } \\
\text { Rivalry among banks } \\
\text { Competition in the } \\
\text { industry } \\
\text { Our bank structure } \\
\text { Our bank culture } \\
\text { Socio-cultural } \\
\text { environment } \\
\text { Our bank ownership } \\
\text { Our bank size } \\
\text { The bank's management } \\
\text { style } \\
\text { Stakeholder expectations } \\
\text { Bank resources } \\
\text { Demography }\end{array}$ & $\begin{array}{l}.886 \\
.777 \\
.624\end{array}$ & .748 & $\begin{array}{l}.699 \\
.844 \\
.709\end{array}$ & $\begin{array}{l}.538 \\
.817\end{array}$ & $\begin{array}{l}.833 \\
.679\end{array}$ & .587 \\
\hline Total variance (\%) & 30.21 & 13.53 & 12.08 & 9.81 & 6.45 & 6.22 \\
\hline
\end{tabular}


European Journal of Business and Innovation Research

Vol.9, No.2, pp. 27-38, 2021

Print ISSN: 2053-4019(Print), Online ISSN: 2053-4027(Online)

\section{RESULTS AND DISCUSSION OF THE FINDINGS}

Table 1 presents the eigenvalue, percentage variance for each of the 19 components. Result obtained reveals that out of the 19 principal components, only 6 components have eigenvalue greater than 1 and the six principal components accounted for $78.296 \%$ of the data set. This implies that there is no much loss of information on the data set. Hence, the dimensionality of the data set can be reduced from 19 components to just 6 components without much loss of information. The PC 1 was found to account for $30.212 \%$ of the variation in the data set while principal components 2, 3, 4, 5 and 6 accounted for $13.52 \%, 12.08 \%, 9.81 \%, 6.45 \%$ and $6.22 \%$ respectively. The number of components with eigenvalues greater than 1 is also depicted using screen plot as shown in Figure 1. The rotated loadings show the relationship between each of the factors that could influence strategic management practices and the extracted 6 principal components and loading less than \pm 0.50 was removed. For principal components 1 which accounted for $30.21 \%$, seven factors loading well and these factors are : Political and legal environment, Economic environment, Technological environment, bargaining power of customers, Socio-cultural environment, The bank's management style and Demography with Political and legal environment having the highest factor loading of .886 followed by Demography (.840) and then Socio-cultural environment(.812).

The second component accounted for $13.53 \%$ of the variation in the data set and factors like global environment (.884) loaded the most followed by bank resources (.778) and then bank ownership (.748). The result also reveals that for principal component 3 with percentage variance of $12.08 \%$, three factors loaded well and are Rivalry among banks (0.709), Competition in the industry (0.709) and bargaining power of customers (0.699). Component 4 accounted for $9.81 \%$ of the variation in the data set and bank size was found to be factors that loaded the most of the component with loading of (.817) followed by Stakeholder expectations (.783) and then bank ownership (.538). The result reveals that only three and two factors loaded well on component 5 and 6 with variance of $6.45 \%$ and $6.22 \%$ respectively. Strategic management practices factors that loaded well on component 5 were new banks in the market (.833), bargaining power of suppliers (.679) and bank structure (0.627). For component 6 , it was bank culture (.872) and threat of substitute products in the market (.587). Therefore, based on the result presented so far, the five major factors that influence strategic management practices are political and legal environment (.886), demography (.840), socio-cultural environment (.812), economic environment (.777) and technological environment (.624). These factors are mostly related to environmental factors.

These findings agrees with that of Kakunu (2012) on factors influencing strategic management practices among commercial banks in Kenya where factors like technological environment, economic environment, legal environment were found to be the most significant factors that influence strategic management among commercial bank in Kenya. This finings also agrees 
European Journal of Business and Innovation Research

Vol.9, No.2, pp. 27-38, 2021

Print ISSN: 2053-4019(Print),

Online ISSN: 2053-4027(Online)

with that of the finding by Simons and Thompson (1998) which also established that environmental factors like technological environment, political, legal environment, and economic environment exert significant influence on strategic management practices. The findings is also consistent with that of other studies (Ogolla, 2007; Kariuki, 2011).

\section{CONCLUSIONS AND RECOMMENDATIONS}

The study has examined some of the factors that influence strategic management practices among commercial banks in Nigeria. The study adopted a multivariate method analysis using Principal Component Analysis (PCA). The findings showed that political and legal environment, demography, socio-cultural environment, economic environment and technological environment were the first five major factors that influence strategic management practice among commercial banks in Nigeria. Also, the findings revealed that strategic management among commercial banks in the study area were highly influenced by the political and legal environment. It was recommended among other things that Commercial banks in Nigeria need to adopt the strategic management models in a way that will help in the achievement of set goals even in a competitive business environment. There is also need for commercial banks in the study area to focus on the environmental factors such as political and legal environment, technological environment, economic environment, global and socio-cultural environment as these affect the practice of strategic management in banks in Nigeria.

\section{Limitations and Suggestions for further study}

Owing to time and cost limitation, the scope of the study was limited to only Commercial banks in Nigeria. Thus, it has not been determined if the result of findings would hold for other industries and it is uncertain whether similar findings would be replicated in other countries.

On the basis of information gathered and the knowledge gained in this study, it is suggested that since the current study scope was limited to only Commercial banks in Nigeria, similar study should be carried out in other industries to ascertain whether the current study findings would hold.

\section{References}

Adeleke, A., Ogundele, O., and Oyenuga, O. (2008), Business Policy and Strategy, 2nd ed. . Lagos: Concept Publications.

Askarany, D., and Yazdifar, H. (2012). Strategic management tools and organisational performance. Paper presented at the American Accounting Association Annual Meeting and Conference on Teaching and Learning Accounting, August 6.

Dominic, T; and Theuvsen, L. (2015) : The impact of external and internal factors on strategic management practices of agribusiness firms in Tanzania, GlobalFood Discussion Papers, No. 55, Research Training Group (RTG) 1666 'GlobalFood', Göttingen. 
European Journal of Business and Innovation Research

Vol.9, No.2, pp. 27-38, 2021

Print ISSN: 2053-4019(Print),

Online ISSN: 2053-4027(Online)

Kakunu, J. M. (2012). Factors influencing strategic management practices among commercial banks in Kenya. A Master of Business Administration Thesis, University of Nairobi, Kenya.

Kariuki, R. (2011), Strategic management in middle tier investment clubs in Nairobi. Unpublished MBA Thesis, University of Nairobi.

Kiptoo, J.K., and Mwirigi, M. F. (2014). Factors that influence effective strategic planning process in organizations. IOSR Journal of Business and Management, 6(2), 188-195.

Mohamud, G.Y., Mohamud, A.S. and Mohamed, B.H. (2015). The relationship between strategic management and Organizational performance in Mogadishu-Somalia. Europeans Journal of Research and Reflection in Management, 3(2), 42-51.

Monday, J.U., Akinola, G.O., Ologbenla, P., and Aladeraji, K.O. (2015). Strategic management and firm performance: A study of selected manufacturing companies in Nigeria. European Journal of Business and Management, 7(2), 161-171.

Muogbo , U. S. (2013). The impact of strategic management on organisational growth and development. A study of selected manufacturing firms in Anambra State. IOSR Journal of Business and Management, 7(1), 24-32.

Olanipekun, W.D., Abioro, D. Akanni, M.A., Arulogun, L.F., Rabiu, O.L., Oloruntoyin, R. (2015). Impact of strategic management on competitive advantage and organisational performance - Evidence From Nigerian Bottling Company. Journal of Policy and Development Studies, 9(2), 185-198.

Sassi,M., Pihlak., U., and Haldma, T. (2017). Factors affecting strategic management attitudes and practices in creative industries organizations. Encatc Journal of Cultural Management \& Policy, 7(1), 71-87.

Theresia, D. and Ludwig, T. (2015). The Impact of Externa and Internal factors on Strtegic Management Practices of Agribusness Firms in Tanzania.

Thompson, A. A., and Strickland, A. J. (2007). Strategic Management: Concepts and Cases (11th ed.). New York: McGraw Hill.

Thompson, A. A., Strickland, A. J., and Gamble, J. E. (2005). Crafting and Executing Strategy: The Quest for Competitive Advantage. New York: McGraw-Hill Irwin.

Thompson, A., and Strickland, A. (2003), Strategic Management: Concepts and Cases, 12th ed. . New York: McGraw-Hill.

Wheelen, T. L., and Hunger, J. D. (2007). Strategic Management and Business Policy (11th ed.). New York: Prentice Hall Inc. 
European Journal of Business and Innovation Research

Vol.9, No.2, pp. 27-38, 2021

Print ISSN: 2053-4019(Print), Online ISSN: 2053-4027(Online)

Zhiping, G.(2016). Factors Affecting Effectiveness Of Strategic Management: Research on Ceramic Business in Kenya. Unpublished MBA Thesis, Chandaria School of Business, Kenya. 